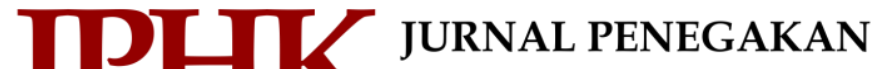 HUKUM DAN KEADILAN}

Vol. 1 No.1, Maret 2020
Gedung Pascasarjana Kampus Terpadu UMY Jalan Brawijaya, Tamantirto, Kasihan, Bantul, Yogyakarta 55183

Telepon : (0274) 387656 Ext. 346

Email : jphk@umy.ac.id

\title{
Penerapan E-Government dalam Menyongsong Era Revolusi Industri 4.0 Kontemporer di Indonesia
}

\author{
Vani Wirawan \\ Magister Hukum, Universitas Muhammadiyah Yogyakarta, \\ Email:vani.wirawan@mail.ugm.ac.id
}

\section{INFO ARTIKEL}

\author{
Perjalanan Artikel: Artikel \\ Dikirimkan oleh penulis: \\ 05-10-19 \\ Artikel Direview: 19-02-20 \\ Artikel Direvisi: 02-03-20 \\ Artikel Diterima atau \\ Dipublikasikan: 04-03-20
}

DOI: 10.18196/jphk.1101

\section{Pendahuluan}

Setelah adanya gerakan reformasi Tahun 1998, paradigma yang berkembang dalam pemerintahan Indonesia adalah tuntutan pelayanan yang lebih baik dari sebelumnya dan terdapatnya ruang bagi masyarakat untuk berpartisipasi dalam kehidupan bernegara. Berdasarkan hal tersebut, maka timbulah istilah clean and good governance di Indonesia, sehingga terciptanya kehidupan yang madani yang berorientasi pada era digitalisasi modern.

Good governance memiliki makna tata pemerintahan yang baik terkait dengan pemerintahan yang bersih (clean governance) dan berwibawa serta bebas Korupsi, Kolusi, Nepotisme (KKN) dengan berprinsip pada transparansi, akuntabilitas, 
menjunjung tinggi hukum, serta terbukanya partisipasi masyarakat. ${ }^{1}$ Untuk mewujudkan clean and good governance terutama dari segi akuntabilitas dan transparansi publik, maka dibutuhkan suatu langkah kebijakan yang terarah dalam perubahan sistem kelembagaan dan ketatalaksanaan melalui pemanfaatan Information and Communication Technologies (ICT) yaitu e-government atau Pemerintahan Elektronik. Sehingga tujuan penyelenggaraan $e$-government adalah untuk meningkatkan partisipasi masyarakat. ${ }^{2}$

E-government merupakan suatu sistem teknologi informasi yang dikembangkan oleh pemerintah untuk meningkatkan pelayanan publik dengan memberikan pilihan kepada masyarakat untuk mendapatkan kemudahan akses informasi publik. ${ }^{3}$ Penyelenggaraan pemerintahan yang baik dan peningkatan layanan publik yang efektif dan efisien diperlukan adanya kebijakan dan strategi pengembangan $e-$ government. Kebijakan dan strategi tersebut diatur dalam Instruksi Presiden Nomor 3 Tahun 2003 tentang Kebijakan dan Strategi Nasional Pengembangan e-government di seluruh jajaran pemerintahan secara menyeluruh. Untuk itu, sosialisasi e-government perlu dilakukan secara konsisten, berkesinambungan dan insentif kepada masyarakat dikarenakan masyarakat belum mengerti apa dan bagaimana aplikasi e-government serta manfaat yang dapat mereka ambil. ${ }^{4}$

Penerapan dan realisasi e-government di Indonesia mengalami tantangan sejak adanya pertumbuhan era industri 4.0, salah satu kendala dalam penerapan $e$ government adalah karena terbatasnya regulasi sebagai payung hukum. Saat ini, belum ada regulasi yang benar-benar menjelaskan secara rinci mengenai mekanisme penerapan e-government berikut dengan tidak seimbangnya perkembangan teknologi yang begitu pesat dan tidak dapat terbendung lagi. Digitalisasi sudah mulai memasuki celah-celah kehidupan kita sehari-hari. Kemajuan teknologi tersebut kemudian banyak dimanfaatkan oleh sektor negeri maupun sektor privat/swasta. Banyak perusahaan bahkan industri kecil kreatif yang menggunakan teknologi digital dalam mengembangkan usaha mereka. Dengan demikian pada penulisan ini akan di uraikan rumusan masalah: pertama bagaimana perkembangan peran e-government dalam menyongsong era revolusi industri 4.0, dan kedua kendala apakah yang mempengaruhi penerapan e-government di Indonesia pada saat ini, serta ketiga

1 Achmad Djunaedi, “Integrasi E-Government: Tantangan, Kebijakan Dan Implementasi, Seminar Pelayanan Publik Dan E-Government," dalam Seminar Pelayanan Publik Dan E-Government (Jakarta: Bappenas, 2008). hlm. 20.

2 Susartono, "E-Government Di Indonesia," Jurnal Ilmu Administrasi Publik volume 2, no. 1 (2006):

3 Kusuma Dewi Arum Sari dan Wahyu Agus Winarno, "Implementasi E-Goverment System Dalam Upaya Peningkatan Clean And Good Goverment Di Indonesia," Jurnal Jeam volume XI, no. 1 (2012): hlm. 2.

Nurcahyani Dewi Retnowati dan Daru Retnowati, "Peranan E-Government Dalam Rangka Mewujudkan Good Governance Bagi Masyarakat," dalam Seminar Nasional Informatika (Yogyakarta: UPN Vetran, 2008), hlm. 210. 
rumusan terbaik untuk mempersiapkan proyeksi e-government terhadap perkembangan revolusi industri 4.0 dimasa yang akan datang.

\section{Metodologi}

Jenis penelitian ini adalah penelitian hukum normatif dengan fokus utama mengkaji bahan-bahan kepustakaan. Penelitian hukum normatif adalah penelitian hukum yang menggunakan data sekunder. Data sekunder berasal dari bahan hukum primer, bahan hukum sekunder dan bahan hukum tersier. Data sekunder yang dicari lebih diutamakan peraturan perundang-undangan yang terkait dengan penerapan $e$ government dalam era revolusi industri 4.0, meskipun demikian data sekunder selain yang bersumber dari bahan hukum primer juga berasal dari bahan hukum sekunder dan bahan hukum tersier yang sangat berkaitan dengan topik penelitian. Pendekatan penelitian yang digunakan adalah pendekatan undang-undang (statute approach) dan pendekatan kasus (case approach).

Cara pengumpulan data penelitian dilakukan dengan metode dokumentasi yaitu merujuk atau mengumpulkan pada bahan-bahan yang didokumentasikan. Sedangkan alat pengumpulan data digunakan studi dokumentasi yaitu studi dengan cara mempelajari data baik berupa buku, laporan hasil penelitian, jurnal, makalah seminar, tulisan para ahli, dan semua peraturan perundang-undangan yang berkaitan dengan materi penelitian. Data penelitian dianalisis dengan analisis isi (content analysis). Analisis isi dilakukan terhadap ke semua data sekunder yang dikumpulkan, namun demikian analisis isi terutama terhadap dokumen yang berupa buku, peraturan perundang-undangan dan jurnal yang relevan.

\section{Analisis dan Hasil}

\subsection{Cakupan Lingkup E-government}

Indrajit menuturkan apabila dilihat dari historis perjalananya, konsep egovernment berkembang karena adanya 3 (tiga) yang melatar belakangi, yaitu: ${ }^{5}$

1) Era globalisasi yang datang lebih cepat dari yang diperkirakan telah membuat isuisu semacam demokratisasi, hak asasi manusia, hukum, transparansi, korupsi, civil society, good corporate governance, perdagangan bebas, pasar Terbuka, dan lain sebagainya menjadi hal-hal utama yang harus diperhatikan oleh setiap bangsa jika yang bersangkutan tidak ingin disingkirkan dari pergaulan dunia. Dalam format ini, pemerintah harus mengadakan reposisi terhadap perannya di dalam sebuah negara, dari yang bersifat internal dan fokus terhadap kebutuhan dalam negeri,

5 Richardus Eko Indrajit, Electronic Government: Strategi Pembangunan Dan Pengembangan Sistem Pelayanan Publik Berbasis Teknologi Digital (Yogyakarta: ANDI, 2016). hlm. 7. 
menjadi lebih berorientasi ke eksternal dan fokus kepada bagaimana memposisikan masyarakat dan negaranya di dalam sebuah pergaulan global. Jika dahulu di dalam sebuah negara kekuasaan lebih berpusat pada sisi pemerintahan (supply side), maka saat ini bergeser ke arah masyarakat (demand side), sehingga tuntutan masyarakat terhadap kinerja pemerintahnya menjadi semakin tinggi (karena untuk dapat bergaul dengan mudah dan efektif dengan masyarakat negara lain, masyarakat di sebuah negara harus memiliki sebuah lingkungan yang kondusif dimana hal ini merupakan tanggung jawab pemerintah).

2) Kemajuan teknologi informasi (komputer dan telekomunikasi) terjadi sedemikian pesatnya sehingga data, informasi dan pengetahuan dapat diciptakan dengan teramat sangat cepat dan dapat segera disebarkan ke seluruh lapisan masyarakat di berbagai belahan dunia dalam hitungan detik. Hal ini berarti bahwa setiap individu di berbagai negara di dunia dapat saling berkomunikasi bersangkutan seperti yang diperlihatkan pada gambar berikut. secara langsung kepada siapapun yang dikehendaki tanpa dibutuhkan perantara (mediasi) apapun. Tentu saja buah dari teknologi ini akan sangat mempengaruhi bagaimana pemerintah di masa moderen harus bersikap dalam melayani masyarakatnya, karena banyak aspekaspek dan fungsi-fungsi pemerintah konvensional yang secara tidak langsung telah diambil alih oleh masyarakatnya sendiri (misalnya masalah pers, sosial, agama, pendidikan, kesehatan, dan lain sebagainya) karena adanya teknologi ini. Inilah alasan lain mengapa pemerintah dipaksa untuk mulai mengkaji fenomena yang ada agar yang bersangkutan dapat secara benar dan efektif mereposisikan peranan dirinya.

3) Meningkatkan kualitas kehidupan masyarakat di dunia tidak terlepas dari semakin membaiknya kinerja industri swasta dalam melakukan kegiatan ekonominya. Kedekatan antara masyarakat (sebagai pelanggan) dengan pelaku ekonomi (pedagang, investor, perusahaan dan lain-lain) telah membuat terbentuknya sebuah standar pelayanan yang semakin membaik dari waktu ke waktu. Percepatan peningkatan kinerja di sektor swasta ini tidak diikuti dengan percepatan yang sama di sektor publik, sehingga masyarakat dapat melihat adanya kepincangan dalam standar kualitas pemberian pelayanan. Dengan kata lain, secara tidak langsung tuntutan masyarakat agar pemerintah meningkatkan kinerjanya semakin tinggi; bahkan jika terbukti terjadinya penyimpanganpenyimpangan dalam pengelolaan uang rakyat, masyarakat tidak segan-segan untuk mengevaluasi kinerja pemerintah melalui demonstrasi atau jalur-jalur lainnya.

Ketiga aspek di atas menyebabkan terjadinya tekanan dari masyarakat yang menginginkan pemerintah memperbaiki kinerjanya secara signifikan dengan cara memanfaatkan teknologi informasi dan komunikasi yang ada. Inisiasi pemerintah 
elektronik dalam e-government itupun kemudian masih terus dikembangkan untuk menjawab tuntutan tersebut.

Di Indonesia e-government sendiri mempunyai arti yang secara khusus yaitu merupakan kegiatan penyelenggaraan pemerintahan yang mampu mendorong dan memfasilitasi hubungan yang saling mendukung, selaras dan adil antara masyarakat, dunia usaha dan pemerintah, dengan memanfaatkan teknologi informasi, telekomunikasi dan web/internet. ${ }^{6}$ Pada dasarnya e-government merupakan penggunaan teknologi informasi yang dapat meningkatkan hubungan antara pemerintah dengan pihak-pihak yang lain. Setidaknya terdapat 4 (empat) klasifikasi hubungan bentuk baru dari penggunaan teknologi informasi dan komunikasi ini : ${ }^{7}$

a. Government to Citizens (G-to-C)

Aplikasi e-government dalam tipe G-to-C ini merupakan aplikasi yang paling umum, dimana pemerintah membangun dan menerapkan berbagai portofolio teknologi informasi untuk berinteraksi dengan masyarakat.

b. Government to Business (G-to-B)

Tipe G-to-B adalah bentuk penyediaan pelayanan informasi bagi kalangan bisnis. Kalangan bisnis semacam perusahaan swasta membutuhkan data dan informasi dari pemerintah. Selain itu, interaksi antara kalangan bisnis dengan lembaga pemerintahan juga berkaitan dengan hak dan kewajiban dari kalangan bisnis tersebut sebagai entity yang berorientasi profit.

c. Government to Government (G-to-G)

Aplikasi e-government juga diperlukan dalam berinteraksi antara satu pemerintah dengan pemerintah lainnya (government to government) untuk memperlancar kerjasama, baik antar negara atau kerjasama antar entiti-entiti negara dalam melakukan hal-hal yang berkaitan dengan administrasi perdagangan, proses-proses politik, mekanisme hubungan sosial dan budaya, dan lain sebagainya.

d. Government to Employees (G-to-E)

Tipe aplikasi G-to-E diperuntukkan secara internal bagi para staf di instansi pemerintahan.

\subsection{Tujuan E-Government}

Ketika pemerintah telah berkomitmen mengembangkan good governance atau ketatapemerintahan yang baik, maka pelayanan publik menjadi salah satu titik strategis yang harus mendapat perhatian khusus. Terdapat beberapa pertimbangan terkait hal tersebut: 8

6 Kusuma Dewi Arum Sari dan Wahyu Agus Winarno, Op.Cit. hlm. 3

7 Diah Rachma Aprianty, "Penerapan Kebijakan E-Government Dalam Peningkatan Mutu Pelayanan Publik Di Kantor Kecamatan Sambutan Kota Samarinda," Jurnal Ilmu Pemerintahan volume 4, no. 4 (2016): hlm. 1593.

8 Agus Dwiyanto, Mewujudkan Good Governance Melalui Pelayanan Publik (Yogyakarta: Gadjah Mada University Press, 2005). hlm. 10. 
1) Pelayanan publik adalah ranah dimana negara berinteraksi secara intensif dengan warganya;

2) Pelayanan publik merupakan ranah dimana berbagai aspek good governance dapat diartikulasikan secara relatif lebih mudah;

3) Pelayanan publik melibatkan kepentingan semua unsur ketatapemerintahan.

Pada intinya, pemerintah berkewajiban memberikan pelayanan publik yang merata kepada seluruh warganya. Perlu disadari bahwa masyarakat menuntut adanya pelayanan publik yang memenuhi kepentingan masyarakat luas di seluruh wilayah negara, dapat diandalkan dan terpercaya, serta mudah dijangkau secara interaktif. ${ }^{9}$ Selain itu, masyarakat juga menginginkan agar aspirasi mereka didengar oleh pemerintah sehingga pemerintahpun harus memfasilitasi partisipasi dan dialog publik didalam perumusan kebijakan negara. Untuk menjawab tantangan tersebut, baik pemerintah pusat maupun daerah harus mampu membentuk dimensi baru ke dalam organisasi, sistem manajemen, dan proses kerjanya yang salah satunya dapat dilaksanakan melalui proses transformasi menuju e-government.

Melalui proses transformasi menuju era e-government tersebut, pemerintah dapat mengoptimalkan penggunaan dan pemanfaatan kemajuan teknologi informasi untuk mengurangi sekat-sekat organisasi birokrasi. Dan lebih fokus membentuk jaringan sistem manajemen proses kerja yang memungkinkan instansi-instansi pemerintah bekerja secara terpadu untuk menyederhanakan akses ke semua informasi pelayanan publik. Dengan demikian seluruh lembaga pemerintah, masyarakat, dunia usaha, dan pihak-pihak berkepentingan lainnya dapat setiap saat memanfaatkan informasi dan layanan pemerintah secara optimal.

Pengembangan e-government merupakan salah satu upaya untuk meningkatkan kualitas layanan publik secara efektif dan efisien. Dengan kata lain, melalui pengembangan e-government dilakukan penataan sistem manajemen dan proses kerja di lingkungan pemerintah dengan mengoptimalkan pemanfaatan teknologi informasi dan komunikasi. Pemanfaatan teknologi informasi tersebut mencakup 2 (dua) aktivitas yang berkaitan yaitu :10

1) Pengolahan data, pengelolaan informasi, sistem manajemen dan proses kerja secara elektronis;

2) Pemanfaatan kemajuan teknologi informasi agar pelayanan publik dapat diakses secara mudah dan murah oleh masyarakat di seluruh wilayah negara.

Untuk melaksanakan maksud tersebut berdasarkan Instruksi Presiden Republik Indonesia Nomor 3 Tahun 2003 tentang Kebijakan dan Strategi Nasional

9 Haryatmoko, “Akuntabilitas Pelayanan Publik: Etika Publik, Dasar Membangun Integritas Dan Profesionalitas," dalam Seminar Indonesia Yang Berkeadilan Sosial Tanpa Dikriminalisasi (Tangerang: UT, 2016).

10 Vita Elysia, Ake Wihadanto, dan Sumartono, "Implementasi E-Government Untuk Mendorong Pelayanan Publik Yang Terintegrasi Di Indonesia," dalam Seminar Optimalisasi Peran Sains Dan Teknologi Untuk Mewujudkan Smart City (Banten: UT, 2017), hlm. 358. 
Pengembangan e-government, pengembangan e-government diarahkan untuk mencapai 4 (empat) tujuan yaitu diantaranya :11

a. Pembentukan jaringan informasi dan transaksi pelayanan publik yang memiliki kualitas dan lingkup yang dapat memuaskan masyarakat luas serta dapat terjangkau di seluruh wilayah Indonesia pada setiap saat tidak dibatasi oleh sekat waktu dan dengan biaya yang terjangkau oleh masyarakat.

b. Pembentukan hubungan interaktif dengan dunia usaha untuk meningkatkan perkembangan perekonomian nasional dan memperkuat kemampuan menghadapi perubahan dan persaingan perdagangan internasional.

c. Pembentukan mekanisme dan saluran komunikasi dengan lembaga-lembaga negara serta penyediaan fasilitas dialog publik bagi masyarakat agar dapat berpartisipasi dalam perumusan kebijakan negara.

d. Pembentukan sistem manajemen dan proses kerja yang transparan dan efisien serta memperlancar transaksi dan layanan antar lembaga pemerintah dan pemerintah daerah otonom.

Inti akhir dari konsep electronic government (e-government) diterapkan dengan tujuan bahwa hubungan pemerintah baik dengan masyarakatnya maupun dengan pelaku bisnis dapat berlangsung secara efisien, efektif dan ekonomis. Hal ini diperlukan mengingat dinamisnya gerak masyarakat pada saat ini, sehingga pemerintah harus dapat menyesuaikan fungsinya dalam negara, agar masyarakat dapat menikmati haknya dan menjalankan kewajibannya dengan aman dan nyaman, yang kesemuanya itu dapat dicapai dengan pembenahan sistem dari pemerintahan itu sendiri, dan e-government adalah salah satu caranya.

Selain itu tujuan penerapan e-government adalah untuk mencapai suatu tata pemerintahan yang baik (good governance). ${ }^{12}$

\subsection{Manfaat E-Government}

Implementasi e-government memiliki banyak manfaat khususnya dalam menunjang efektivitas dan efisiensi dalam pelayanan publik. Manfaat-manfaat tersebut diantaranya adalah $: 13$

1) Mengurangi Biaya

Memberikan pelayanan secara on-line atau dalam jaringan dapat secara signifikan mengurangi total biaya administrasi, relasi, dan interaksi yang

11 Ibid. hlm. 359.

12 Ayu Aditya Oktavya, "Penerapan (Electronic Government) E-Government Pada Kantor Pelayanan Pajak Pratama Dalam Pemberian Pelayanan Di Kota Bontang," Jurnal Ilmu Pemerintahan volume 3, no. 3 (2015): hlm. 1437.

13 Satyabrata Dash and Subhendu Kumar Pani, "E-Governance Paradigm Using Cloud Infrastructure: Benefits and Challenges," Procedia Computer Science 85 (2016): hlm. 844. 
dikeluarkan pemerintah maupun stakeholdernya dibandingkan pelayanan secara manual.

2) Mendukung Perkembangan Ekonomi

Teknologi dapat memudahkan pemerintahan dalam menciptakan iklim bisnis yang positif dengan menyederhanakan tahapan administrasi atau mengurangi birokrasi. Selain itu, terdapat dampak langsung terhadap ekonomi, misalnya seperti dalam e-procurement atau proses lelang secara elektronik dimana menciptakan kompetisi yang lebih luas dan lebih banyak peserta.

3) Memperkuat Transparansi dan Akuntabilitas

Implementasi e-government dapat meningkatkan transparansi, kontrol, dan akuntabilitas penyelenggaraan pemerintahan dalam rangka penerapan konsep Good Corporate Governance. e-government membantu meningkatkan transparansi dalam proses pengambilan keputusan dengan penyediaan informasi serta pelacakan dalam jaringan (on-line tracking) yang mudah diakses oleh masyarakat.

4) Meningkatkan Pelayanan bagi Masyarakat

E-government dapat memberikan layanan yang lebih baik pada masyarakat dimana informasi dari pemerintah dapat dicari atau diperoleh tanpa harus secara fisik datang ke kantor-kantor pemerintahan. Bahan-bahan informasi tersebut tersedia dalam 24 jam sehari dan tujuh hari dalam seminggu tanpa harus bergantung pada jam operasional kantor-kantor pemerintah.

5) Memberdayakan Masyarakat

Pemberdayaan masyarakat dilaksanakan melalui informasi yang mudah diperoleh yang kemudian memungkinkan masyarakat dan pihak-pihak lain sebagai mitra pemerintah terlibat dalam proses pengambilan keputusan atau kebijakan publik secara merata dan demokratis.

6) Fasilitas E-Society

Salah satu manfaat utama dari inisiatif e-Governance terdiri dari promosi penggunaan ICT di sektor lain. Kapasitas teknologi dan manajemen yang diperlukan untuk administrasi e-Government mendorong pengembangan kursus dan modul pelatihan baru di sekolah dan universitas yang berusaha memasok yang diperlukan keterampilan dan kapabilitas ke pasar kerja.

Harapan dikembangkannya e-government ini, akses informasi pada pemerintah akan menjadi terbuka lebar bagi semua lapisan masyarakat. Oleh karenanya apabila diimplementasikan dengan tepat maka secara signifikan dapat memperbaiki kuwalitas kehidupan masyarakat tersebut. Mengingat banyaknya manfaat dari sistem $e$ government ini, implementasinya haruslah dilaksanakan sesegera mungkin, tanpa ditunda-tunda. Selain itu, sistem ini perlu dibangun dengan kepemimpinan yang baik dan kerangka pengembangan yang holistik, sehingga memberikan keunggulan kompetitif secara nasional. 


\subsection{Peran E-Government Sebagai Bagian dari Smart Government dalam Mendukung dan Menyongsong Era Revolusi Industri 4.0}

Beberapa waktu lalu dalam acara Indonesia Industrial Summit 2018 Presiden Republik Indonesia Joko Widodo meluncurkan peta jalan (road map) "Making Indonesia 4.0" yang merupakan strategi nasional dalam menghadapi era Revolusi Industri 4.0. Dengan diluncurkannya peta jalan tersebut pemerintah kini berpacu mempersiapkan diri untuk menghadapi gelombang disrupsi teknologi. Sosialisasi terus digalakkan baik dibidang industri, ekonomi hingga pendidikan.

Berdasarkan Pasal 1 ayat (1) Undang-Undang Nomor 25 Tahun 2009 tentang Pelayanan Publik, Pelayanan Publik merupakan kegiatan atau rangkaian kegiatan dalam rangka pemenuhan kebutuhan pelayanan sesuai dengan peraturan perundangundangan bagi setiap warga negara dan penduduk atas barang, jasa dan/atau pelayanan administrasi yang diselenggarakan oleh penyelenggara pelayanan publik.

Keterkaitan pelayanan publik dan era revolusi Industri 4.0 saat ini sebetulnya telah jelas terdapat di dalam Undang-Undang Nomor 25 Tahun 2009 tentang Pelayanan Publik ada Pasal yang mengatur bahwasanya Pelayanan Publik harus mempunyai sistem yang dapat memberikan kemudahan kepada masyarakat. Merujuk pada Pasal 23 ayat (1) Undang-Undang Nomor 25 Tahun 2009 tentang Pelayanan Publik, disebutkan bahwa "Dalam rangka memberikan dukungan informasi terhadap penyelenggaraan pelayanan publik perlu diselenggarakan Sistem Informasi yang bersifat nasional" sementara di Pasal 23 ayat (4) Undang-Undang Nomor 25 Tahun 2009 tentang Pelayanan Publik, penyelenggara berkewajiban mengelola Sistem Informasi yang terdiri atas Sistem Informasi Elektronik atau Non elektronik yang sekurang-kurangnya meliputi; profil penyelenggara, profil pelaksana, standar pelayanan, maklumat pelayanan, pengelola pengaduan dan penilaian kinerja.

Setiap penyelenggara pelayanan publik diwajibkan untuk menyediakan sistem informasi secara nasional. Dengan begitu tidak lain teknologi informasi berperan besar dalam rangka pemenuhan sistem untuk skala nasional. Sehingga sudah seharusnya menjadi perhatian pemerintah untuk dapat menyesuaikan penyelenggaraan pelayanannya kepada masyarakat dalam menghadapi Revolusi Industri 4.0 saat ini, yaitu dengan menerapkan pelayanan publik yang berbasis teknologi. Dikarenakan dengan teknologi, transparansi, kecepatan, kemudahan yang menjadi kunci pada suatu pelayanan akan terwujud, maka tidak heran pelayanan di sektor privat/swasta biasanya akan lebih baik karena pemanfaatan teknologi yang semakin canggih dalam proses pemberi pelayanannya untuk menjaga kepercayaan pelanggan sehingga usaha yang dijalankan akan terus produktif.

Pemerintah sebagai penyelenggara pelayanan publik mempunyai kewajiban menyediakan tranparansi sistem informasi terlebih jumlah konsumen yang mengakses pelayanan di sektor publik lebih besar dibandingkan disektor private/swasta. Maka apabila pemerintah ingin mendapatkan kepercayaan dari konsumen dalam hal ini masyarakat seharusnya pemerintah mulai serius untuk memanfaatkan teknologi 
digital diera Revolusi Industri 4.0, dalam penyelenggaraan pelayanan publik. Dengan tujuan bukan hanya sektor privat/swasta saja yang dapat mengambil keuntungan dari sebuah kemajuan teknologi saat ini tetapi juga disektor negeri/publik.

Sebenarnya saat ini Kementerian Pendayagunaan Aparatur Negara dan Reformasi Birokrasi (MenpanRB) sebagai kementerian yang membantu Presiden dalam menyelenggarakan pemerintahan sudah mengundangkan Peraturan Menteri Pendayagunaan Aparatur Negara dan Reformasi Birokrasi Republik Indonesia Nomor 13 Tahun 2017 tentang Pedoman Penyelenggaraan Sistem Informasi Pelayanan Publik Nasional (SIPPN). Di dalam Peraturan tersebut pada Pasal 3 disebutkan bahwa Menteri, Pimpinan Lembaga, Gubernur, Bupati, Walikota, Direktur Utama BUMN, Direktur Utama BUMD wajib memastikan penyediaan informasi pelayanan publik ke dalam SIPPN setelah berlakunya Peraturan Menteri Pendayagunaan Aparatur Negara dan Reformasi Birokrasi sesuai dengan ketentuan peraturan perundang-undangan.

Setelah satu tahun lebih peraturan tersebut diundangkan baru-baru ini Menpan RB meluncurkan aplikasi SIPPN yang dapat diakses melalui http://sipp.menpan.go.id. sebagai wadah informasi pelayanan publik semua instansi penyelenggara pelayanan publik secara nasional mulai dari pemerintah daerah, kementrian/lembaga, lembaga non struktural dan BUMN/BUMD. Namun, SIPPN yang sedang dikembangkan oleh Menpan RB tersebut masih belum sempurna dikarenakan belum semua pemerintah daerah maupun kementerian/lembaga menginput data infromasi pelayanan publik dimasing-masing instansinya ke aplikasi SIPPN di http://sipp.menpan.go.id. tersebut. Lemahnya kewenangan Menpan RB untuk mendorong instansi tersebut untuk mengintegrasikan data pelayanan publik tiap instansi ke aplikasi SIPPN menjadi salah satu kendala belum efektifknya aplikasi tersebut. Padahal, dengan SIPPN pelayanan publik di Indonesia akan saling terintegrasi. Sehingga bertujuan semua informasi terkait pelayanan publik dapat diakses melalui aplikasi SIPPN tersebut, selain itu SIPPN merupakan wujud pengawasan dan partisipasi masyarakat yang efektif sehingga tercegahnya penyalahgunaan kewenangan dalam penyelenggaraan pelayanan publik.

Secara global, pelayanan publik menjadi kunci kemenangan dalam persaingan. Salah satu indikasinya dalam Ease of Doing Business (EoDB) 2018 peringkat Indonesia saat ini berada pada posisi ke-72 dari 190 negara yang disurvei. Peringkat ini sebenarnya merupakan sebuah lompatan dari EoDB 2017 yang sebelumnya berada di ranking 91. Kuncinya adalah pelayanan publik, karena ukuran masing-masing indikator yang diteliti adalah standar pelayanan, berupa prosedur, waktu, dan biaya. Guna meningkatkan kualitas pelayanan publik menjadi kelas dunia, Kementerian Pendayagunaan Aparatur Negara dan Reformasi Birokrasi mengadakan sosialisasi di berbagai wilayah. Sementara itu, Pendaftaran Kompetisi Inovasi Pelayanan Publik tahun 2018 ini dilakukan secara online mulai dari 17 Januari sampai dengan 10 Maret 2018 melalui http:/ / sivonik.menpan.go.id. 
Sistem e-government yang merupakan upaya pemerintah dalam mengimplementasikan pemanfaatan komputer, jaringan komputer dan teknologi informasi untuk menjalankan pemerintahan terutama pelayanan publik masih sangat minim. Masih sedikit Kementerian/Lembaga maupun Pemerintah Daerah yang memanfaatkan teknologi dalam proses pelayanan publik. Padahal jika e-government sendiri diterapkan disetiap pemerintahan maka hal tersebut sejalan dengan Revolusi Industri 4.0.

E-government memiliki banyak manfaat dalam sistem berdemokrasi yang saat ini kita terapkan diantaranya meningkatkan kecepatan komunikasi antara pemerintah, masyarakat, swasta, maupun koordinasi antar instansi yang berbasis internet. Selain itu untuk mewujudkan pelayanan yang transparan, meningkatkan akuntabilitas dari proses penyelengaraan pemerintahan, menghemat anggaran pemerintah, serta memudahkan alur informasi yang dapat diakses secara terbuka guna mewujudkan cita-cita good governance dan open government pada penyelenggaraan pemerintahan di Indonesia.

Mengutip pernyataan Dunleavy saat memperkenalkan konsep digital governance pada tahun 2005 sebagai pengganti New Public Management (NPM) yang banyak diadopsi di pemerintahan mengatakan, begitu pentingnya digital dalam tata kelola pemerintahan. Bahkan Profesor Bidang Politik dan Kebijakan Publik London School of Economics adn Political Science (LSE) juga menyatakan bahwa "New Publik Management is Dead, Long Live Digital Era Governance". Dengan kata lain era digital yang saat ini kita hadapi pada Revolusi Indsutri 4.0 dalam tata kelola pemerintahan mau tidak mau harus segera diimplementasikan.

Penerapan dan pengembangan e-government selain dibutuhkan dukungan teknologi yang handal, juga sangat ditentukan oleh dukukungan kompetensi Sumber Daya Manusia (SDM) staf/pegawai setiap unit kerja. Jumlah SDM yang sudah memapu menggunakan komputer sudah memadai, hal ini ditunjukkan bawa 25\% responden menyatakan bahwa jumlah SDM yang mampu menggunakan komputer pada unit kerjanya kurang dari 10 orang, $25 \%$ responden menyatakan antara 10 s.d. 25 orang. $25 \%$ responden menyatakan antara 25 s.d. 50 orang, dan $25 \%$ responden menyatakan lebih dari 100 orang. Latar belakang pendidikan komputer staf/pegawai yang mampu menggunakan komputer ditunjukkan bahwa 50\% responden menyatakan pendidikan sarjananya, 25\% menyatakan karena diplomanya, 25\% menyatakan karena pelatihannya, 50\% menyatakan karena kursusnya, dan 75\% menyatakan karena belajar sendiri. ${ }^{14}$

Implementasi e-government akan optimal apabila semua staf/pegawai berkompeten memanfaatkan semua fasilitasnya sesuai tupoksi dan manajemen masing-masing. Untuk dapat memanfaatkan e-government secara optimal. Semua responden menyatakan bahwa semua SDM membutuhkan tambahan pendidikan

14 Achmad Habibullah, "Kajian Pemanfaatan Dan Pengembangan E-Government," Jurnal Privat Law volume 23, no. 3 (2010): hlm. 194-195. 
khusus kompetensi pemanfaatan e-government. $75 \%$ responden menyatakan perlunya tambahan pendidikan khusus bidang kompetensi Programmer e-government, 75\% menyatakan perlunya bidang kompetensi internet, $100 \%$ menyatakan perlunya tambahan kompetensi teknisi komputer, 75\% menyatakan perlunya tambahan kompetensi operator, dan $75 \%$ menyatakan perlunya tambahan kompetensi pengolah kata dan data. Adapun prioritas tambahan pendidikan khusus yang dibutuhkan dinyatakan oleh $50 \%$ responden menyatakan bidang kompetensi programmer, dan $50 \%$ responden lainnya tidak memberikan jawaban. ${ }^{15}$

Untuk mendukung tambahan pendidikan khusus bidang e-government, 50\% responden menyatakan perlunya kebijakan pimpinan tentang tugas belajar bagi staf/pegawai melalui tugas belajar sambil bekerja, dan 50\% responden menyatakan perlunya izin belajar penuh. Saran-saran lain yang berkembang dari responden perlunya peta pengemabangan SDM bidang e-government. ${ }^{16}$

E-government sebaiknya disosialisasikan kepada seluruh elemen masyarakat. Dari data tersebut menunjukkan bahwa SDM sudah siap untuk dapat menerapkan $e^{-}$ government. Namun demikian, masih dibutuhkan komimen semua pihak untuk meningkatkan kompetensi e-government masing-masing staf/pegawai sesuai tupoksi, manajemen, dan kemampuannya.

\subsection{Kendala yang Mempengaruhi Terhadap Penerapan E-Government di Indonesia Pada Saat Ini}

Ada beberapa hal yang menjadi hambatan atau tantangan dalam mengimplementasikan e-government di Indonesia untuk menyongsong revolusi industry 4.0 diantaranya ${ }^{17}$ : (1) Kultur berbagi (sharrring) informasi belum ada, (2) Kultur mendokumentasi belum lazim, (3) Langkanya SDM yang handal dibidang TI, (4) Infrastruktur yang belum memadai dan mahal, (5) Tempat akses informasi yang terbatas.

Retnowati mengatakan ${ }^{18}$ faktor - faktor penentu keberhasilan penerapan egovernment adalah: (1) Kebutuhan seperti apa yang saat ini menjadi prioritas utama dari masyarakat di negara atau di daerah terkait, (2) Infrastruktur telekomunikasi, (3) Tingkat konektivitas dan penggunaan TI oleh pemerintah, (4) Kesiapan SDM di pemerintah, (5) Ketersediaan dana dan anggaran, (6) Ketersediaan perangkat hukum, (7) Perubahan paradigma cara kerja dan perilaku SDM aparatur. Sehingga factor yang paling urgent dalam lingkup SDM adalah masalah kurangnya sampai saat ini tenaga ahli di bidang IT yang mumpuni di Indonesia, dan masih banyaknya aparat di pemerintahan yang masih gaptek (gagap teknologi) terkhususnya bagi generasi yang sudah tua yg masih mengisi di segmen-segmen pemrintahan sampai saat ini.

Menurut analisis penulis ada tiga hal persoalan kendala mendasar di dalam penyelenggaran e-government tersebut berada ditingkat pemerintahan daerah

15 Ibid. hlm. 195.

16 Ibid.

17 Achmad Habibullah, Op.Cit

18 Nurcahyati Dewi dan Daru Retnowati, Op.Cit. hlm. 206. 
diantaranya yaitu ; pertama, inisiatif dan pemaknaan implementasi e-government oleh pemerintah daerah otonom masih bersifat sendiri-sendiri. Kedua, implementasi melalui situs web daerah tersebut belum didukung oleh sistem manajemen dan proses kerja yang efektif karena kesiapan peraturan, prosedur dan keterbatasan sumber daya manusia. Ketiga, banyak pemerintah daerah mengidentikkan implementasi $e$ government hanya sekadar membuat situs web pemda saja (web presence), sehingga penyelenggaraan e-government hanya berhenti ditahap pematangan saja dari 4 tahap yang harus dilalui.

\subsection{Rumusan Terbaik Proyeksi E-Government Terhadap Perkembangan Revolusi Industri 4.0 Dimasa yang Akan Datang}

Ketika komputer diperkenalkan dalam Industri 3.0, saat itu dianggap sebagai hal asing yang kemudian menjadi sesuatu yang ditambahkan pada teknologi yang sama sekali baru. Sekarang, dan pada waktu-waktu mendatang seiring dengan kian terbukanya Industri 4.0, komputer-komputer akan berkomunikasi satu sama lain untuk pada akhirnya membuat keputusan tanpa campur tangan manusia. Kendati ada yang menyebut bahwa revolusi Industri 4.0 ini hanyalah bahasa pemasaran (marketing), namun terjadi perubahan-perubahan dalam cara produksi dan manufaktur yang mau tak mau menarik perhatian kita.

Dalam revolusi keempat ini, kita menghadapi serangkaian teknologi baru yang mengombinasikan dunia fisika, digital, dan dunia biologi. Teknologi-teknologi baru ini akan berdampak pada semua disiplin, ekonomi dan industri, bahkan akan menantang ide kita tentang arti manusia. Teknologi ini memiliki potensi besar menghubungkan miliaran manusia melalui web, meningkatkan efisiensi bisnis dan organisasi secara drastis, dan membantu regenerasi lingkungan alami melalui manajemen aset yang lebih baik, mengurangi kerusakan yang diakibatkan revolusi industri sebelumnya.

Namun demikian ada juga potensi risikonya. Professor Klaus Schwab, Pendiri dan Executive Chairman the World Economic Forum dalam bukunya The Fourth Industrial Revolution menyebutkan, bahwa organisasi-organisasi bisa jadi tak mampu atau tak mau mengadaptasi teknologi baru ini dan pemerintah mungkin gagal meregulasi teknologi ini secara layak. Dalam bukunya, Schwab berteori bahwa perubahan daya akan menciptakan masalah-masalah keamanan yang penting, dan kesenjangan bisa jadi akan kian membesar, bukannya berkurang jika segala sesuatunya tidak diatur secara benar. Sebagai misal, seiring dengan meningkatnya otomasi, komputer dan mesin akan menggantikan pekerja di banyak spektrum dari industri, mulai dari sopir, akuntan, agen properti hingga agen asuransi. Diperkirakan sebanyak 47\% dari lapangan kerja di Amerika Serikat akan terancam akibat otomatisasi. Banyak ahli mengindikasikan bahwa revolusi Industri 4.0 akan lebih menguntungkan kalangan kaya daripada kalangan miskin, terutama karena hilangnya pekerjaan-pekerjaan bergaji rendah yang hanya memerlukan ketrampilan rendah, karena digantikan oleh 
mesin-mesin otomatis. Namun itu bukan hal baru. Secara historis, revolusi industri selalu diawali dengan jurang kesenjangan yang besar sebelum diikuti oleh periode perubahan politik dan institusional.

Demikian dari apa yang diutarakan diatas diharuskan adanya rumusan proyeksi e-government dimasa yang akan datang baik masa revolusi industri 4.0 berlangsung dan maupun dimasa regenerasinya, untuk mengantisipasi hal-hal yang disebutkan diatas baik yang berupa akibat baiknya dan akibat potensi resikonya. Beberapa rumusan terbaik itu diataranya adalah:

1) Tatanan regulasi hukum yang baik dan perlindungan hukum;

2) Pemerintah meningkatkan pendidikan terkususnya di bidang IT sebagai pembentukan SDM yang mumpuni;

3) Infrastuktur dan ketersediaan media akses yang memadai;

4) Pembentukan karakter dan etos kerja yang baik bagi SDM aparatur pemerintahan;

5) Merubah mindset aparatur menjadi disruptive mindset aparatur di Indonesia;

6) Revolusi industri 4.0 berbasis revolusi moral;

7) Menciptakan Intrepreneurial Leadership yang handal;

8) Diperkuatnya pendidikan agama;

Semua kemampuan dan proyeksi diatas tidak lepas dari dasar kemampuan dan kemauan yang kuat dari pemerintah sekarang ini. Secara logis selaras dengan adanya kematangan dalam penguatan ekonomi berkesinambungan yang baik dalam penerapan e-government masa revolusi industri 4.0 kontemporer ini di Indonesia, sehingga kedepan akan tercipta checks and balances di semua struktur.

\section{Kesimpulan}

E-Government merupakan suatu sistem IT yang dikembangkan oleh pemerintah dalam memberikan pilihan kepada masyarakat, untuk mendapatkan kemudahan mengakses informasi dan pelayanan publik guna mewujudkan clean and good governance pada suatu negara. Perkembangan sistem e-government di Indonesia secara kuantitas mulai meningkat namun secara kualitas masih belum memadai dikarenakan implementasi e-government belum merata pada seluruh wilayah dan masih berfungsi sebagai penyedia informasi statik saja. Guna meningkatkan pengembangan egovernment di Indonesia baik dari segi kuantitas maupun kualitas diperlukannya komitmen pemerintah dalam melakukan penyempurnaan pengembangan $e$-government terutama dari segi infrastruktur, SDM, aplikasi, regulasi serta sosialisasi di internal pemerintah maupun kepada masyarakat.

Beberapa persoalan kendala mendasar di dalam penyelenggaran e-government dalam revolusi industri 4.0 pada saat ini berada ditingkat pemerintahan daerah diantaranya yaitu ; pertama, inisiatif dan pemaknaan implementasi e-government oleh pemerintah daerah otonom masih bersifat sendiri-sendiri. Kedua, implementasi melalui situs web daerah tersebut belum didukung oleh sistem manajemen dan proses kerja yang efektif karena kesiapan peraturan, prosedur dan keterbatasan sumber daya 
manusia. Ketiga, banyak pemerintah daerah meng-identikkan implementasi $e$ government hanya sekadar membuat situs web pemda saja (web presence), sehingga penyelenggaraan e-government hanya berhenti ditahap pematangan saja dari 4 tahap yang harus dilalui.

Proyeksi e-government terhadap perkembangan revolusi industri 4.0 dimasa yang akan datang haruslah adanya rumusan terbaik diantaranya: (1) Tatanan regulasi hukum yang baik dan perlindungan hukum. (2) Pemerintah ‘meningkatkan pendidikan terkususnya di bidang IT sebagai pembentukan SDM yang mumpuni. (3) Infrastuktur dan ketersediaan media akses yang memadai. (4) Pembentukan karakter dan etos kerja yang baik bagi SDM aparatur pemerintahan. (5) Merubah mindset aparatur menjadi disruptive mindset aparatur di Indonesia. (6) Revolusi industri 4.0 berbasis revolusi moral. (7) Menciptakan Intrepreneurial Leadership yang handal. (8) Diperkuatnya pendidikan agama.

E-government merupakan alat pendukung tercapainya clean and good governance, karena di Indonesia masih baru mengimplementasikan e-government dan belum berkembang cepat maka clean and good governance di Indonesia belum tercapai. Namun tidak menutup kemungkinan pada masa mendatang pengembangan implementasi $e$ government Indonesia akan berhasil.

\section{Daftar Pustaka}

Aprianty, Diah Rachma. "Penerapan Kebijakan E-Government Dalam Peningkatan Mutu Pelayanan Publik Di Kantor Kecamatan Sambutan Kota Samarinda." Jurnal Ilmu Pemerintahan volume 4, no. 4 (2016).

Dash, Satyabrata, and Subhendu Kumar Pani. "E-Governance Paradigm Using Cloud Infrastructure: Benefits and Challenges." Procedia Computer Science 85 (2016).

Djunaedi, Achmad. "Integrasi E-Government: Tantangan, Kebijakan Dan Implementasi, Seminar Pelayanan Publik Dan E-Government." In Seminar Pelayanan Publik Dan E-Government. Jakarta: Bappenas, 2008.

Dwiyanto, Agus. Mewujudkan Good Governance Melalui Pelayanan Publik. Yogyakarta: Gadjah Mada University Press, 2005.

Elysia, Vita, Ake Wihadanto, and Sumartono. "Implementasi E-Government Untuk Mendorong Pelayanan Publik Yang Terintegrasi Di Indonesia." In Seminar Optimalisasi Peran Sains Dan Teknologi Untuk Mewujudkan Samrt City, hlm. 358. Banten: UT, 2017.

Habibullah, Achmad. "Kajian Pemanfaatan Dan Pengembangan E-Government." Jurnal Privat Law volume 23, no. 3 (2010).

Haryatmoko. "Akuntabilitas Pelayanan Publik: Etika Publik, Dasar Membangun Integritas Dan Profesionalitas." In Seminar Indonesia Yang Berkeadilan Sosial Tanpa Dikriminalisasi. Tangerang: UT, 2016. 
Indrajit, Richardus Eko. Electronic Government: Strategi Pembangunan Dan Pengembangan Sistem Pelayanan Publik Berbasis Teknologi Digital. Yogyakarta: ANDI, 2016.

Oktavya, Ayu Aditya. "Penerapan (Electronic Government) E-Government Pada Kantor Pelayanan Pajak Pratama Dalam Pemberian Pelayanan Di Kota Bontang." Jurnal Ilmu Pemerintahan volume 3, no. 3 (2015).

Retnowati, Nurcahyani Dewi, and Daru Retnowati. "Peranan E-Government Dalam Rangka Mewujudkan Good Governance Bagi Masyarakat." In Seminar Nasional Informatika, hlm. 210. Yogyakarta: UPN Vetran, 2008.

Sari, Kusuma Dewi Arum Winarno, Wahyu Agus. "Implementasi E-Goverment System Dalam Upaya Peningkatan Clean And Good Goverment Di Indonesia." Jurnal Jeam volume XI, no. 1 (2012).

Susartono. “E-Government Di Indonesia." Jurnal Ilmu Administrasi Publik volume 2, no. 1 (2006).

Undang-Undang Nomor 25 Tahun 2009 tentang Pelayanan Publik.

Instruksi Presiden Republik Indonesia Nomor 3 Tahun 2003 tentang Kebijakan dan Strategi Nasional Pengembangan E-government.

Peraturan Menteri Pendayagunaan Aparatur Negara dan Reformasi Birokrasi Republik Indonesia Nomor 13 Tahun 2017 tentang Pedoman Penyelenggaraan Sistem Informasi Pelayanan Publik Nasional (SIPPN). 